\title{
Enhancement of the antioxidant and skin permeation properties of eugenol by the esterification of eugenol to new derivatives
}

\author{
Edyta Makuch ${ }^{1 *} \mathbb{0}$, Anna Nowak ${ }^{2 *}$, Andrzej Günther ${ }^{1}$, Robert Pełech ${ }^{1}$, Łukasz Kucharski² ${ }^{2}$ Wiktoria Duchnik $^{2}$
} and Adam Klimowicz ${ }^{2}$

\begin{abstract}
The aim of the study was to determine the antioxidant activity and assess the lipophilicity and skin penetration of eugenyl chloroacetate (EChA), eugenyl dichloroacetate (EDChA), and eugenyl trichloroacetate (ETChA). Identification of the obtained products was based on gas chromatography (GC), infrared spectroscopy (FTIR/ATR), gas chromatography coupled with mass spectrometry (GC-MS), and the analysis of ${ }^{13} \mathrm{C}-\mathrm{NMR}$ and ${ }^{1} \mathrm{H}-\mathrm{NMR}$ spectra. The antioxidative capacity of the derivatives obtained was determined by the DPPH free radical reduction method, while the octanol/ water partition coefficient (shake-flask method) was tested to determine the lipophilicity of these compounds. In the next stage of testing EDChA and ETChA-(compounds characterized by the highest degree of free radical scavenging), the penetration of DPPH through pig skin and its accumulation in the skin were evaluated. For comparison, penetration studies of eugenol alone as well as dichloroacetic acid (DChAA) and trichloroacetic acid (TChAA) were also carried out. The antioxidant activity (DPPH, ABTS, and Folin-Ciocalteu methods) of the fluid that penetrated through pig skin was also evaluated. The in vitro pig skin penetration study showed that eugenol derivatives are particularly relevant for topical application. The obtained derivatives were characterized by a high level of antioxidant activity estimated after $24 \mathrm{~h}$ of conducting the experiment, which indicates long-term protection against reactive oxygen species (ROS) in the deeper layers of the skin.
\end{abstract}

Keywords: Eugenol, New esters of eugenol, log P, Skin penetration, Franz cell, Antioxidant activity

\section{Key points}

- New esters of eugenol show potent antioxidant activity in vitro.

- There are new eugenol derivatives to penetrate easily through biological membranes.

\footnotetext{
*Correspondence: emakuch@zut.edu.pl; anowak@pum.edu.pl

1 Department of Chemical Organic Technology and Polymeric Materials, Faculty of Chemical Technology and Engineering, West Pomeranian University of Technology, Szczecin, Pulaskiego 10, 70-322 Szczecin, Poland

${ }^{2}$ Department of Cosmetic and Pharmaceutical Chemistry, Pomeranian Medical University in Szczecin, Powstańców Wielkopolskich Ave. 72, 70-111 Szczecin, Poland
}

- Presented esters can provide exogenous and endogenous action against free radicals.

\section{Introduction}

Reactive oxygen species (ROS) are important factors in the ageing process that are formed during incomplete reduction of oxygen molecules in the respiratory chain. When there is an imbalance between reactive oxygen species and the body's antioxidant potential, oxidative stress occurs. It is widely recognized that reactive oxygen species (ROS) contribute to the aging of the skin, which is the external barrier of our body. However, many 
tissues inside our body are also subjected to ROS. In fact, the human body is exposed to both endogenous and exogenous ROS effects. These compounds, which cause oxidative stress, are responsible for oxidative modifications of polyunsaturated fatty acids and nucleic acids (as a consequence, this leads to structural changes in cell membranes as well as to DNA damage). Antioxidants are compounds characterized by the ability to deactivate free radicals responsible for the ageing process of the body (Dhale et al. 2007; Michalak et al. 2014; Igielska-Kalwat et al. 2015; Agati et al. 2012; Zhao 2015; Suvarnakuta et al. 2011; Li and Seeram 2010; Janiuk et al. 2013). To assess their antioxidant properties, in vitro methods are mainly used, and these are based on two types of reactions: the HAT (hydrogen atom transfer) technique and the SET (single electron transfer) method. The first method is related to the transfer of a hydrogen atom derived from an antioxidant, while the second method involves the transfer of a single electron from an antioxidant molecule (Zheng 2017; Makuch et al. 2019). The most commonly used methods for assessing the antioxidant properties of compounds include the ferric ion reducing antioxidant parameter (FRAP) method, the method using the ABTS reagent (2,2'-azino-bis(3-ethylbenzothiazoline-6-sulfonic acid), determination of total polyphenol content using the Folin-Ciocalteu reagent, and the method for determining the antioxidant activity using the DPPH radical (2,2-diphenyl-1-picrylhydrazyl) (Gulcin 2011; Molyneux 2004; Li et al. 2011; Benzie and Strain 1996). In spectroscopic methods, the quantitative analysis of antioxidant capacity is based on the change in absorbance of the test solution (Gulcin 2011; Molyneux 2004; Li et al. 2011; Benzie et al. 1996).

The DPPH radical is a dark purple color and has a maximum absorbance at $\lambda=515-517 \mathrm{~nm}$. The method of measuring the antioxidant capacity of compounds using the DPPH technique is based on a spectrophotometrically recorded change in the color of the ethanol solution of the DPPH radical. The reaction of the DPPH radical with an antioxidant occurs on one of the nitrogen atoms present in the DPPH molecule (on the so-called nitrogen bridge). When the DPPH radical is transferred to the hydrogen atom present at the antioxidant hydroxyl group, the dark violet color of the DPPH ethanol solution changes to light yellow or the solution completely discolors; thus, the absorbance of the tested solution decreases (Gulcin 2011; Molyneux 2004; Li et al. 2011).

Literature reports indicate that clove oil, eugenol, and esters obtained by esterifying eugenol with acetic anhydride or benzoic acid (eugenyl acetate and eugenyl benzoate) are characterized by the ability to deactivate free radicals (Horchani et al. 2010; Vanin et al. 2014; Sá et al.
2017). Besides, eugenol, eugenyl acetate, eugenyl propionate, eugenyl butyrate and eugenyl 4-ethyl, 4-fluoro, 4-chloro and 4-bromobenzoate are also characterized by antimicrobial activity (Rahim 2017; Chaibakhsh et al. 2012; Cichorek et al. 2013). Other literature reports indicate that eugenol and eugenyl acetate are also characterized by anti-tumour activity against the B16 melanoma cell line, as assessed by the method described by Arung et al. $(2007,2011)$.

The results of our previous preliminary studies related to the assessment of antioxidant activity showed that products obtained by the esterification of eugenol with the appropriate carboxylic acid chloride compounds are characterized by their ability to react with the free radical DPPH (Makuch et al. 2019). The natural consequence of this trend is the synthesis and evaluation of antioxidant activity of the chloro-, dichloro-, and trichloroacetate derivatives. In addition to antioxidant activity, antioxidants should be characterized by an adequate level of penetration through the stratum corneum of the skin into its inner deeper layers. The indicator of the hydrophilicity and hydrophobicity of compounds is the octanol/water partition coefficient $(\log$ P). By increasing the lipophilicity of eugenol through its esterification, the penetration of obtained ester derivatives through cell membranes is facilitated (Malinowska et al. 2013). The stratum corneum is a physical, environmental, and microbiological barrier that protects the body against external factors. It is mainly made of lipid substances such as ceramides, cholesterol, fatty acids, cholesterol esters, and phospholipids present in the stratum corneum in small amounts. These substances can significantly inhibit the penetration of exogenous compounds (both therapeutic and cosmetic) into the deeper layers of the skin. Also, the nature of the outer layer means that lipophilic substances penetrate it much more easily than the hydrophilic compounds that accumulate in it (Jaworska et al. 2011). By giving active substances adequate lipophilicity, their penetration is increased while their accumulation is limited. This phenomenon is particularly important in the case of active substances such as added antioxidants that are characterized by high antioxidant activity in both the stratum corneum of the skin and in its deeper layers (IIntarakumhaeng and Li 2014; Zhang et al. 2016). Therefore, the use of eugenol ester derivatives as active substances with high antioxidant activity and higher lipophilicity (compared to eugenol and the acids from which these derivatives were obtained) can be an alternative for obtaining cosmetic preparations characterized by longlasting protection against free radicals (ROS).

As part of the research, eugenyl chloro-, dichloro-, and trichloroacetate were obtained by reacting eugenol with 
chloro-, dichloro-, and trichloroacetic acid chlorides. Esters were synthesized as described in our previous publication (Makuch et al. 2019). The selectivity of the conversion to EChA, EDChA, and ETChA as well as the conversion of eugenol were determined by the gas chromatography (GC) method, while the molar masses of the obtained products were confirmed based on the mass spectrum (GC-MS). The most important band associated with the presence of an ester group in the structure of the obtained products was identified by infrared spectroscopy. The unequivocal confirmation of the structure of new eugenol ester derivatives not yet described in the literature was carried out by NMR. The antioxidative activity and the octanol/water partition coefficient of eugenol and its esters were evaluated by the spectrophotometric method.

The penetration through pig skin using the Franz diffusion cell, accumulation of two derivatives (EDChA and ETChA) in the skin, eugenol content, as well as DChAA and TChAA contents were evaluated. Moreover, the antioxidant potential of solutions applied to the skin and obtained after $24 \mathrm{~h}$ of penetration through the skin as well as the activity of the skin after the test were assessed.

\section{Materials and methods Chemicals}

The following compounds were used for the synthesis of eugenol esters: chloroacetic acid (Sigma-Aldrich, 99\%), dichloroacetic acid (Sigma-Aldrich, $\geq 99 \%$ ), trichloroacetic acid (Chempur, 99\%), oxallyl chloride (Alfa Aesar, 98\%), eugenol (Keten, p.a.), pyridine (AR Ubichem), dimethylformamide (DMF, Acros, 99\%), chloroform (Chempur, p.a.), and deionized water.

The amounts of these compounds were selected to maintain the molar ratio of carboxylic acid:oxalyl chloride:eugenol:amines as 81:71:51:123. For the determination of antioxidant activity and to assess the lipophilicity of the esters obtained, 2,2-diphenyl-1-picrylhydrazyl (DPPH), 6-hydroxy-2,5,7,8-tetramethylchroman-2-carboxylic acid (trolox), 2,2'-azino-bis(3-ethylbenzothiazoline-6-sulfonic acid) (ABTS), and sodium lauryl sulfate were purchased from Sigma Aldrich (USA); Folin-Ciocalteu reagent, disodium phosphate (p.a.), and potassium dihydrogen phosphate (p.a.) were purchased from Merck, Darmstadt, Germany; ethanol (96\% v/v), methanol (50\% $\mathrm{v} / \mathrm{v}$, concentrated) (all of the analytical grade) sodium chloride, potassium chloride, and gallic acid (GA) were purchased from Chempur, Piekary Śląskie (Poland); and acetonitrile for HPLC was purchased from J.T. Baker, PBS.

\section{Synthesis and characterization of new esters}

First, EChA, EDChA, and ETChA were obtained by the method described in our previous publication (Makuch et al. 2019). After synthesis, the obtained products were identified by mass spectrometry coupled with gas chromatography (GC-MS). Chromatographic analyses were performed with a TRACE GC series apparatus with a VOYAGER mass detector using a DB5 capillary column $(30 \mu \times 0.25 \mu \mathrm{m} \times 0.5 \mu \mathrm{m})$. The following separation parameters were used for the analysis: helium flow of $1.0 \mathrm{ml} / \mathrm{min}$, sample chamber temperature of $240{ }^{\circ} \mathrm{C}$, and detector voltage of $350 \mathrm{~V}$. The thermostat temperature increased according to the following program: isothermal at $50{ }^{\circ} \mathrm{C}$ for $1 \mathrm{~min}$, increase at a rate of $8{ }^{\circ} \mathrm{C} / \mathrm{min}$, isothermal at $260{ }^{\circ} \mathrm{C}$ for $5 \mathrm{~min}$, and then cooled to $50{ }^{\circ} \mathrm{C}$. The sample partition coefficient in the dispenser was 20 , the volume of dispensed sample was $0.1 \mu \mathrm{l}$, and the ion mass range was $25-350 \mathrm{mV} / \mathrm{z}$.

The degree of conversion of eugenol and the purity of the obtained products were determined by gas chromatography (GC). Chromatographic analyses were performed on a FOCUS apparatus (Thermo Electron) with a flame ionization detector (FID) and a RESTEK RTX-5 capillary column $(0.53 \mathrm{~mm} \times 30 \mathrm{~m} \times 1.5 \mu \mathrm{m})$. Infrared spectroscopy (FTIR/ATR) was characterized by functional groups present in the structures of the products obtained. Analyses were performed on a THERMO NICOLED 380 apparatus using a measuring range of $4000-400 \mathrm{~cm}^{-1}$. The same method also used eugenol for comparative purposes.

The structures of the obtained esters (dissolved in deuterated chloroform $\left(\mathrm{CDCl}_{3}\right)$ ) were confirmed based on the analysis of nuclear magnetic resonance (NMR) spectroscopy spectra, which was performed with a Bruker DPX-400 spectrometer. The conditions for recording ${ }^{13} \mathrm{C}$-NMR spectra were as follows: $100.62 \mathrm{MHz}$, a spectrum width of $24 \mathrm{kHz}, 65.5 \mathrm{~K}$ data points, a resolution of $1.46 \mathrm{~Hz} /$ point, a data acquisition time of $1.37 \mathrm{~s}$, a repetition time of $1 \mathrm{~s}$, a pulse width of $9.2 \mu \mathrm{s}$, and 1-8 scans. In addition, ${ }^{1} \mathrm{H}$-NMR spectra were recorded under the following conditions: $400.13 \mathrm{MHz}$, a $12 \mathrm{kHz}$ spectrum width, $65.5 \mathrm{~K}$ data points, a $0.488 \mathrm{~Hz} /$ point resolution, a data acquisition time of $4.09 \mathrm{~s}$, a repetition time of $1 \mathrm{~s}$, a $7.8 \mu$ s pulse width, and 16-32 scans.

On the ${ }^{1} \mathrm{H}$-NMR spectrum, which is presented in Fig. 1, the presence of clear peaks indicating the presence of certain groups of protons in the structure of the tested ester was observed. The proton signals recorded as intense peaks corresponded to hydrogen atoms from groups belonging to hydrocarbon chains, indicating the presence of an aromatic system in the molecule of the compound tested. The analysis of the ${ }^{13} \mathrm{C}$-NMR spectrum presented in Fig. 2 supplemented the information obtained based 


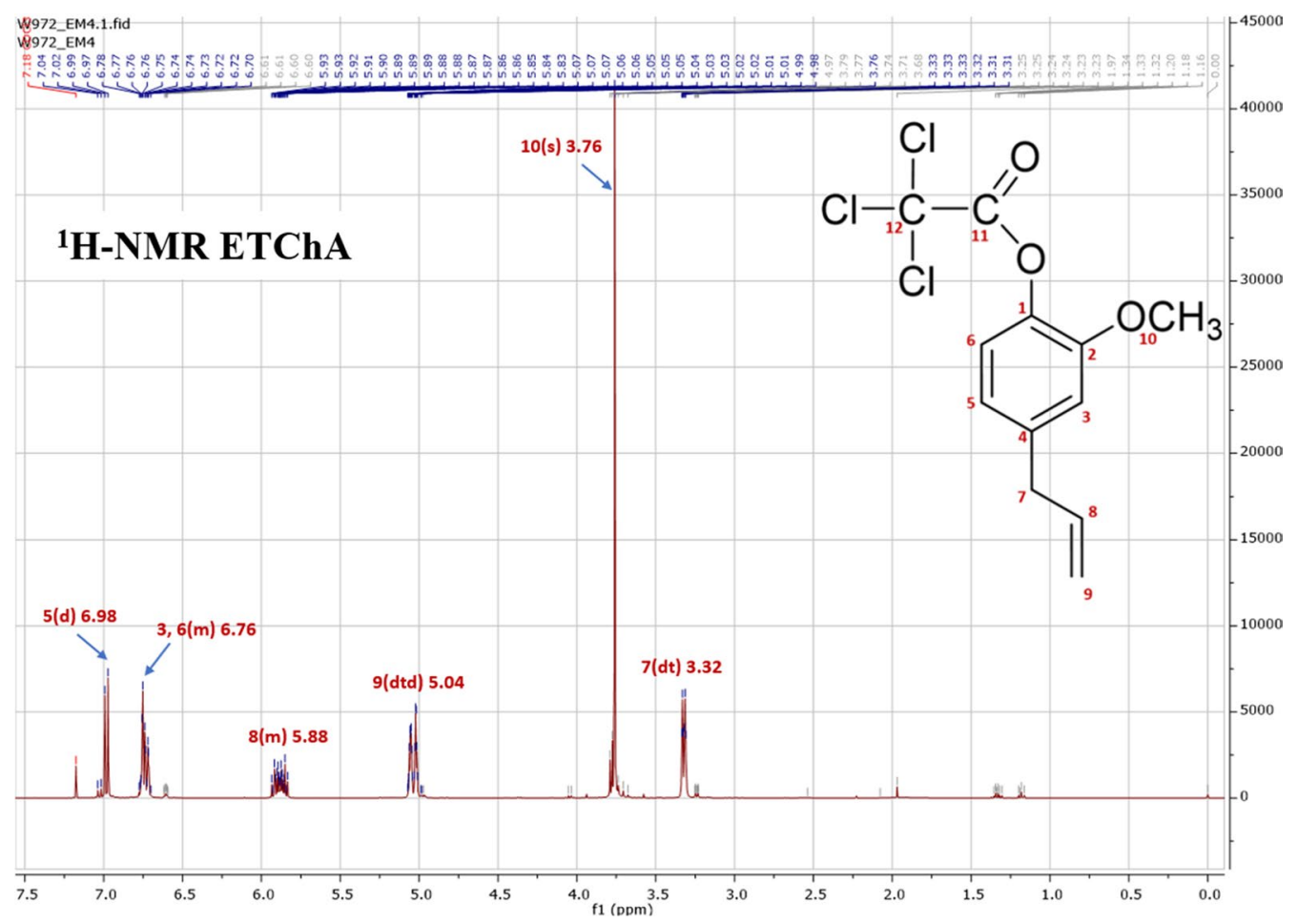

Fig. $1{ }^{1} \mathrm{H}-\mathrm{NMR}$ spectrum of ETChA

on the interpretation of the ${ }^{1} \mathrm{H}-\mathrm{NMR}$ spectrum and additionally confirmed the structure of the obtained ester. The chemical shift values of carbon atoms and protons as well as the signals assigned to atoms ${ }^{13} \mathrm{C}$ and ${ }^{1} \mathrm{H}$ were as follows:

${ }^{13} \mathrm{C}-\mathrm{NMR}\left(101 \mathrm{MHz}, \mathrm{CDCl}_{3}\right) \delta 160.24,150.51,140.43$, $137.71,136.75,121.45,120.77,116.50,116.46,89.54$, 56.04, 40.09;

${ }^{1} \mathrm{H}$ NMR $\left(400 \mathrm{MHz}, \mathrm{CDCl}_{3}\right) \delta 6.98(\mathrm{~d}, J=8.0 \mathrm{~Hz}, 1 \mathrm{H})$, 6.80-6.67 (m, 2H), 5.97-5.81 (m, $1 \mathrm{H}), 5.04(\mathrm{dtd}, J=14.7$, $3.4,1.7 \mathrm{~Hz}, 2 \mathrm{H}), 3.76(\mathrm{~s}, 3 \mathrm{H}), 3.32(\mathrm{dt}, J=6.7,1.5 \mathrm{~Hz}, 2 \mathrm{H})$.

For the remaining esters, the chemical shift values of carbon atoms and protons and the signals assigned to atoms ${ }^{13} \mathrm{C}$ and ${ }^{1} \mathrm{H}$ were as follows:

${ }^{13} \mathrm{C}-\mathrm{NMR}\left(101 \mathrm{MHz}, \mathrm{CDCl}_{3}\right) \delta 165.62,150.59,139.66$, $137.55,136.91,122.13,120.72,116.34,112.82,55.86$, 40.71, 40.10 - (EChA);

${ }^{1} \mathrm{H}$ NMR $\left(400 \mathrm{MHz}, \mathrm{CDCl}_{3}\right) \delta 6.90(\mathrm{~d}, J=7.9 \mathrm{~Hz}, 1 \mathrm{H})$, 6.80-6.65 (m, 2H), $5.88(\mathrm{ddt}, J=17.0,10.3,6.8 \mathrm{~Hz}, 1 \mathrm{H})$, 5.11-4.97 (m, 2H), $4.25(\mathrm{~s}, 2 \mathrm{H}), 3.73(\mathrm{~s}, 3 \mathrm{H}), 3.30(\mathrm{dt}$, $J=6.8,1.5 \mathrm{~Hz}, 2 \mathrm{H})-(\mathrm{EChA})$;
${ }^{13} \mathrm{C}-\mathrm{NMR}\left(101 \mathrm{MHz}, \mathrm{CDCl}_{3}\right) \delta 162.84,150.65,140.24$, 137.42, 136.91, 121.81, 120.86, 116.55, 113.12, 64.14, 56.08, 40.20 - (EDChA);

${ }^{1} \mathrm{H}$ NMR $\left(400 \mathrm{MHz}, \mathrm{CDCl}_{3}\right) \delta 7.02(\mathrm{~d}, J=8.0 \mathrm{~Hz}, 1 \mathrm{H})$, 6.83-6.80 (m, 1H), $6.78(\mathrm{q}, J=1.9 \mathrm{~Hz}, 1 \mathrm{H}), 6.19(\mathrm{~s}, 1 \mathrm{H})$, $5.96(\mathrm{ddt}, J=9.4,17.6 \mathrm{~Hz}, 1 \mathrm{H}), 5.11(\mathrm{dt}, 2 \mathrm{H}), 3.83(\mathrm{~s}, 3 \mathrm{H})$, $3.39(\mathrm{dd}, J=1.6,6.8 \mathrm{~Hz}, 2 \mathrm{H})$ - (EDChA).

\section{Measurement of lipophilicity of eugenol and new esters}

To determine the lipophilicity of eugenol and its ester derivatives, the values of the $\mathrm{n}$-octanol/water partition coefficient $(\mathrm{P})$ were examined. Determining the lipophilicity of a substance involves determining its partition coefficient between two immiscible liquids: n-octanol and water (which model the properties of cell structures well). The partition coefficient was expressed as the logarithm ratio of substance concentrations in both phases (Piwowarczyk et al. 2017):

$$
\log \mathrm{P}=\log \mathrm{C}_{\mathrm{n} \text {-octanol }}-\log \mathrm{C}_{\text {water }},
$$

where $\mathrm{P}$ is the partition coefficient, $\mathrm{C}_{\mathrm{n} \text {-octanol }}$ is the concentration of the compound in the octanol phase, and 


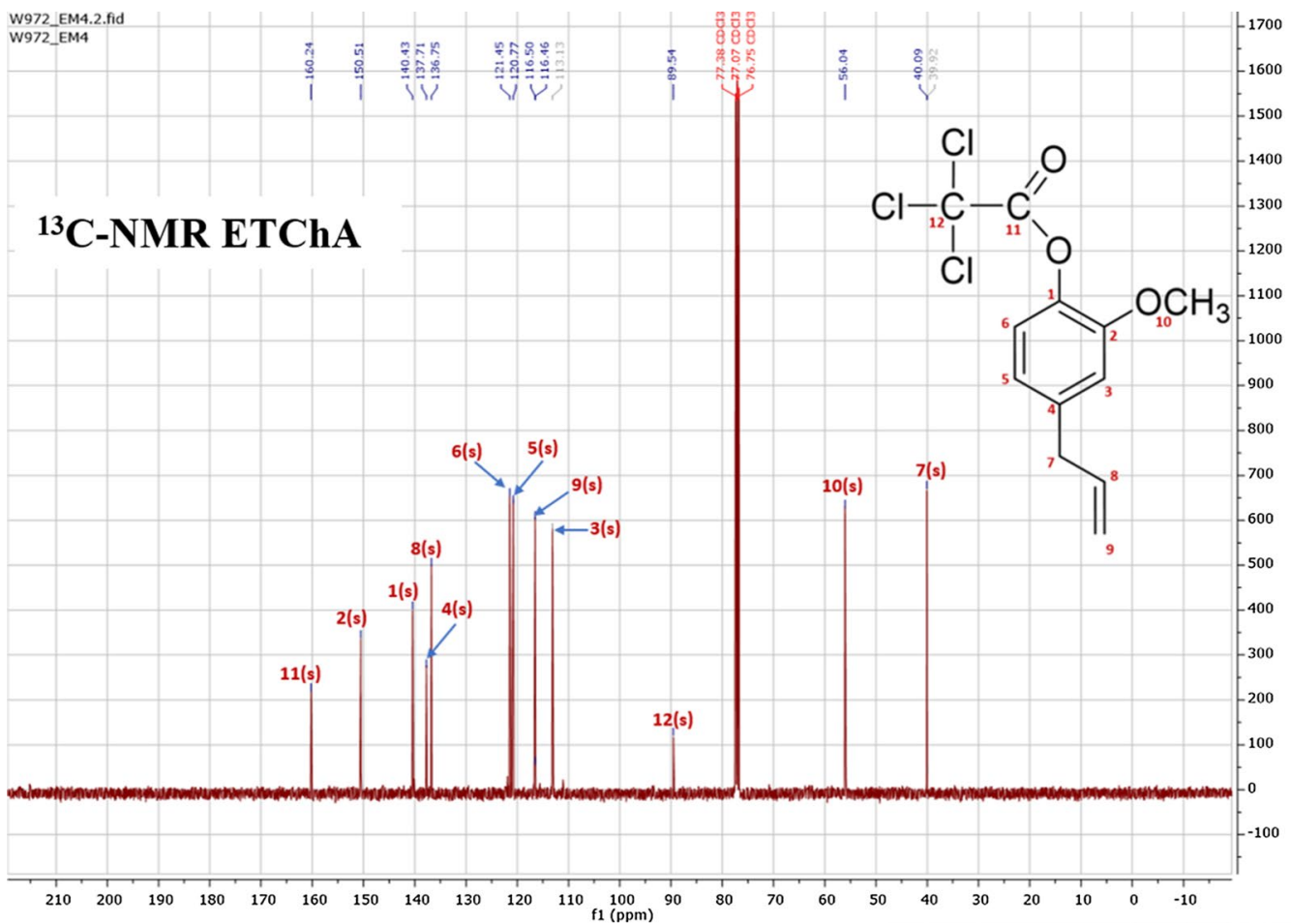

Fig. $2{ }^{13} \mathrm{C}-\mathrm{NMR}$ spectrum of ETChA

$\mathrm{C}_{\text {water }}$ is the concentration of the compound in the aqueous phase.

$\mathrm{N}$-octanol was mixed with water in a 1:1 ratio containing the test compound at a concentration of 32.00$178.00 \mathrm{mg} / 100 \mathrm{ml}$ solution. The mixture was then shaken on a shaker (TS-2 Orbital Shaker) for $24 \mathrm{~h}$ at a constant temperature of $25^{\circ} \mathrm{C}$, which was controlled by an immersion thermostat. Concentrations of substances in the analyzed samples were determined by spectrophotometry at the following wavelengths: $279 \mathrm{~nm}$ (in the case of eugenol), $272 \mathrm{~nm}$ (in the case of EChA), $277 \mathrm{~nm}$ (in the case of EDChA), and $280 \mathrm{~nm}$ (in the case of ETChA). For comparison purposes, log P values for DChAA and TChAA were also determined by potentiometric method. Furthermore, blanks were performed for each compound tested. For this purpose, n-octanol was mixed with water in a 1:1 ratio, and then the mixture was shaken for $24 \mathrm{~h}$ under constant temperature conditions, after which the aqueous layers were analyzed by a spectrophotometric method using appropriate wavelengths $\lambda$ (Piwowarczyk et al. 2017).

Furthermore, compounds contained in aqueous solutions were identified by thin-layer chromatography (TLC). Based on the obtained chromatograms, the retention factor $\left(R_{f}\right)$ values for the corresponding ester and pure eugenol were determined. The absence of eugenol in aqueous solutions of the esters tested indicated a lack of the hydrolysis of these compounds (Waszczuk and Makuch et al. 2020).

\section{Measurement of the antioxidant capacity using DPPH, ABTS and Folin-Ciocalteu methods}

Studies on the antioxidant activity of eugenol and its esters were carried out by free radical reduction (DPPH) (Brand-Williams et al. 1995; Nowak et al. 2017), ABTS (Nowak et al. 2017), and the Folin-Ciocalteu method (Nowak et al. 2019). The ABTS assay is based on the generation of a blue/green ABTS, which is applicable to both hydrophilic and lipophilic antioxidant systems; whereas DPPH assay uses a radical dissolved in organic media and is, therefore, applicable to hydrophobic systems (Floegel et al. 2011).

The analyses were performed on a Merck Spectroquant Pharo 300 apparatus at the following wavelengths $\lambda: 517 \mathrm{~nm}$ (in the case of the DPPH method), $734 \mathrm{~nm}$ (in the case of the ABTS method), and $765 \mathrm{~nm}$ (in the case of the Folin-Ciocalteu method). Trolox was used as a reference substance in the DPPH and ABTS methods, while gallic acid was used as a standard to assess the polyphenol contents in the sample tested by the Folin-Ciocalteu method. The antioxidant activity results obtained by these methods are expressed in $\mathrm{mmol} / \mathrm{dm}^{3}$.

The antioxidant activity of eugenol and its ester derivatives was measured as follows: $2850 \mu \mathrm{l}$ of an ethanol 
solution with the DPPH radical was introduced into the tube, and its absorbance at $\lambda=517 \mathrm{~nm}$ was about $1.000 \pm 0.020$ with $150 \mu \mathrm{l}$ of the ethanol solution containing the tested antioxidant. The tube was wrapped in aluminum foil and its contents were sealed with a stopper and then incubated for $10 \mathrm{~min}$ at room temperature. After this time, spectrophotometric measurements were carried out at the appropriate wavelength and in triplicate.

First, an aqueous solution of potassium persulfate $(2.45 \mathrm{mM})$ was prepared, in which an appropriate amount of ABTS reagent was introduced to obtain a $7 \mathrm{mM}$ solution of ABTS in an aqueous solution of potassium persulfate. The solution prepared in this way was incubated at $4{ }^{\circ} \mathrm{C}$ for $24 \mathrm{~h}$ and then diluted with methanol $(50 \% \mathrm{v} / \mathrm{v})$ to obtain an absorbance of approximately $1.000 \pm 0.020$.

The antioxidant activity of eugenol and its ester derivatives was measured as follows: $2500 \mu \mathrm{l}$ of prepared ABTS solution and $25 \mu \mathrm{l}$ of an ethanol solution with the tested antioxidant were introduced into the spectrophotometric cuvette. The cuvette was sealed with a stopper and then incubated for $6 \mathrm{~min}$ at room temperature. After this time, the spectrophotometric measurement was carried out at the appropriate wavelength and in triplicate.

This method is based on the use of the Folin-Ciocalteu reagent (takes place in an alkaline medium), which is used to determine the total content of phenolic compounds found in the tested samples. The reaction is based on the spectrophotometrically recorded color change of the test solution from yellow to blue.

Two hundred microliters of Folin-Ciocalteu reagent in $1800 \mu \mathrm{l}$ of water was dissolved in a dark bottle. The solution prepared in this way was incubated at room temperature for $60 \mathrm{~min}$. The antioxidant activity of eugenol and its ester derivatives was measured as follows: $1350 \mu \mathrm{l}$ of distilled water and $1350 \mu \mathrm{l}$ of sodium carbonate solution $\left(0.01 \mathrm{~mol} / \mathrm{dm}^{3}\right)$ were introduced into the spectrophotometric cuvette with $150 \mu \mathrm{l}$ of the prepared Folin-Ciocalteu solution and $150 \mu \mathrm{l}$ of an ethanol solution containing the tested antioxidant. The cuvette was sealed with a stopper and then incubated for $15 \mathrm{~min}$ at room temperature. After this time, spectrophotometric measurements were carried out at the appropriate wavelength and in triplicate.

\section{Skin permeation studies of eugenol and new esters}

Porcine skin was used for the study due to its similar properties permeability to human skin (Čuř́ková et al. 2017; Janus et al. 2020). The skin came from a local slaughterhouse. A fresh portion of skin from the abdomen was washed several times with a solution of $\mathrm{PBS}$ at $\mathrm{pH}$ 7.4. Skin with a thickness of $0.5 \mathrm{~mm}$ was cut with a dermatome, and then it was wrapped in aluminum foil and frozen at $-20{ }^{\circ} \mathrm{C}$ for a maximum of 3 months. This freezing time ensured the stability of the skin barrier properties (Badran et al. 2009). Before the examination, the skin was thawed at room temperature for about $30 \mathrm{~min}$, and then it was soaked in a PBS solution for $15 \mathrm{~min}$ to hydrate it (Haq et al. 2018; Kuntsche et al. 2008; Simon et al. 2016). In the next stage, the skin was mounted in Franz diffusion cells.

The integrity of skin was checked $1 \mathrm{~h}$ after its installation in the Franz diffusion chamber (SES GmbH Analyze Systeme, Germany). Skin impedance was measured using an LCR 4080 meter (Conrad Electronic, Germany) operating in parallel mode at $120 \mathrm{~Hz}$ $(\mathrm{k} \Omega$ error $<0.5 \%)$. To make the measurement, the tips of the probes were immersed in the donor and acceptor chambers filled with the PBS solution (Kopečná et al. 2017). Membranes with an electrical resistance of $>3 \mathrm{k} \Omega$, corresponding to the resistance measured for human skin, were used in the study (Davies et al. 2004).

The penetration of eugenol and its ester derivatives was assessed in a Franz diffusion chamber consisting of a $2 \mathrm{ml}$ donor chamber and an $8 \mathrm{ml}$ acceptor chamber. The area through which the tested active ingredients permeated was $1 \mathrm{~cm}^{2}$. The acceptor fluid, mixed with a magnetic stirrer, was a PBS solution that maintained the physiological $\mathrm{pH}$. The acceptor chamber was kept at a constant temperature of $37 \pm 0.5^{\circ} \mathrm{C}$ with the VEB MLW Prüfgeräte-Werk type 3280 thermostat. Before starting the test, Franz diffusion cells were allowed to equilibrate at $37^{\circ} \mathrm{C}$ for $15 \mathrm{~min}$. After this time, ethanol solutions of test compounds (at a concentration of $1 \%$ $\mathrm{w} / \mathrm{v}$ ) were placed in the donor chamber. For the study, $500 \mu \mathrm{L}$ of the ethanol solution of the test compound (at a concentration of $1 \% \mathrm{w} / \mathrm{v}$ ) was applied to the outer layer of the skin in each donor chamber to ensure continuous delivery of the active substance during the experiment. All donor chambers were closed with a plastic stopper to prevent excessive evaporation of the solution. The described tests were carried out for 24 $\mathrm{h}$, while $0.3 \mathrm{ml}$ of the solution located in the acceptor chamber was taken at specified intervals $(30 \mathrm{~min}$, $1 \mathrm{~h}, 2 \mathrm{~h}, 3 \mathrm{~h}, 4 \mathrm{~h}, 5 \mathrm{~h}, 8 \mathrm{~h}$ and $24 \mathrm{~h}$ ), and then supplemented with a fresh portion buffer at the same $\mathrm{pH}$ (Kopečná et al. 2017). The samples were analyzed by high-performance liquid chromatography (HPLC) with a UV spectrophotometric detector (Knauer, Berlin, Germany). The components tested were separated on a $125 \times 4 \mathrm{~mm}$ column containing Hyperisil ODS; particle size $5 \mu \mathrm{m}$. The flow rate of the mobile phase, consisted of acetonitrile, water, and $\mathrm{MeOH}$ (28:64:8, by vol) was $1 \mathrm{ml} / \mathrm{min}$. Twenty microliters of each analyzed sample was injected onto the column. 
After the experiment was carried out, the skin was extracted to estimate the residual volume of tested active ingredients accumulated in it. The antioxidant activity of the obtained extracts was also tested using modified methods described in (Brand-Williams et al. 1995; Nowak et al. 2017; Nowak et al. 2019). Extraction was carried out as follows: after the experiment was completed, the Franz diffusion chambers were dismantled, while the skin surface was washed three times with an aqueous solution of sodium lauryl sulfate (at a concentration of $0.5 \% \mathrm{w} / \mathrm{w}$ ) to elute the ethanol solution of the test compound. A patch $\left(1 \mathrm{~cm}^{2}\right.$ diffusion surface) was cut from the skin prepared in this way, dried at room temperature, and then weighed and cut into smaller pieces. Then, $2 \mathrm{ml}$ of concentrated methanol was added to it, and extraction was carried out for $24 \mathrm{~h}$ at $4{ }^{\circ} \mathrm{C}$. After $24 \mathrm{~h}$ of incubation, the skin was homogenized (for $3 \mathrm{~min}$ ) using a homogenizer (IKA ${ }^{\circledR} \mathrm{T} 18$ digital ULTRA TURRAX, Germany). The extracts obtained were then centrifuged at $3500 \mathrm{rpm}$ for $5 \mathrm{~min}$. The supernatant was analyzed by HPLC to determine the content of active ingredients, while to evaluate the antioxidant activity of the obtained extracts the DPPH, Folin-Ciocalteau, and ABTS methods were applied.

The cumulative mass of active substance $(\mu \mathrm{g})$ permeating into the receptor chamber was calculated based on the concentrations of compounds determined by HPLC. The permeation rate was determined based on the amount of permeation of a compound over a given period $\left(\mu \mathrm{g} / \mathrm{cm}^{2} / \mathrm{h}\right)$. The accumulation of compounds in the skin was calculated by determination of remaining ingredients in the liquid obtained after skin extraction; the results are given in $\mu \mathrm{g} / \mathrm{cm}^{2}$ of skin.

The antioxidant activity of solutions of test compounds applied to the skin, acceptor fluid taken after $24 \mathrm{~h}$ of penetration, and solutions obtained after skin extraction taken at the end of the experiment was determined using the DPPH, Folin-Ciocalteau, and ABTS methods, as described in sections: measurement of the antioxidant capacity of eugenol and new esters using the DPPH, the ABTS and the Folin-Ciocalteu methods.

Statistical calculations were done using Statistica 13 PL software (StatSoft, Polska). The results were evaluated using one-way analysis of variance (ANOVA). Significant differences between the permeation of individual compounds were evaluated using Tukey post-hoc test. Probabilities $<0.05$ were considered to be statistically significant. Results are presented as the mean \pm standard deviation (SD).

\section{Results}

Research by the GC method showed that the process yielded eugenol esters as the main products with $100 \%$ selectivity, with eugenol conversion of $99.7 \%$ (in the case of EChA and ETChA) and $99.8 \%$ (in the case of EDChA).

Based on the results obtained by the GC-MS method (presented in Fig. 3), in the esterification process of eugenol with chloroacetic acid chloride, one product was obtained with the following masses $(\mathrm{m} / \mathrm{z}): 240(73 \%)$, 242 (24\%), and $243(3 \%)$. These results correspond to the calculated mass of EChA $(240.5 \mathrm{~g} / \mathrm{mol})$ (Fig. 3a). In the esterification process of eugenol with dichloroacetic acid chloride, one product was obtained with the following masses (m/z): $274(56 \%), 276(38 \%)$, and $278(6 \%)$. The molecular weight of the identified product corresponds to the mass of EDChA (274.9 g/mol) (Fig. 3b). By esterifying eugenol with trichloroacetic acid chloride, one product was obtained with the following masses $(\mathrm{m} / \mathrm{z}): 308$ (43\%), 310 (41\%), $312(15 \%)$, and $314(1 \%)$. The molecular weight of the obtained ester corresponds to the mass of ETChA (309.5 g/mol) (Fig. 3c).

The IR ETChA spectrum, which is shown in Fig. 4, has an absorption band characteristic of the ester group at a wavelength of about $1775 \mathrm{~cm}^{-1}$. Also, there is no wideband at a wavelength of about $3500 \mathrm{~cm}^{-1}$, which is attributed to the stretching vibration of $\mathrm{O}-\mathrm{H}$ bonds. However, this band occurs in the eugenol molecule. Besides, absorption bands were observed at a wavelength of about $3010 \mathrm{~cm}^{-1}$ (derived from $\mathrm{CH}$ carbon atoms with $\mathrm{sp}^{2}$ hybridization) and at a wavelength of about $1637 \mathrm{~cm}^{-1}$ (associated with the presence of $\mathrm{C}=\mathrm{C}$ carbon atoms), which occur in both the allyl group as well as in the aromatic ring of eugenol and its ester. In the IR spectrum of eugenol and ETChA, absorption bands were measured at wavelengths of about $2976 \mathrm{~cm}^{-1}$ (attributed to $\mathrm{CH}$ carbon atoms with $\mathrm{sp}^{3}$ hybridization) and about $1300-1118 \mathrm{~cm}^{-1}$ (found on carbon in the aromatic ring), derived from the methoxy group (Kuo et al. 2009; Ginting et al. 2019). In the case of the remaining esters (EChA and EDChA), the same functional groups that were present in the structure of ETChA were observed.

Table 1 presents a comparison of octanol/water partition coefficient values determined by the experimental method and calculated in the MestReNova program.

Each compound's lipophilicity is represented as the decimal logarithm of the partition coefficient (Piwowarczyk et al. 2017). Results are presented as the mean \pm standard deviation (SD). The partition coefficient $(\log \mathrm{P})$ values for eugenol and its ester derivatives, determined using the theoretical calculation method, were slightly higher than the log $\mathrm{P}$ values obtained by the spectrophotometric method (Table 1). 

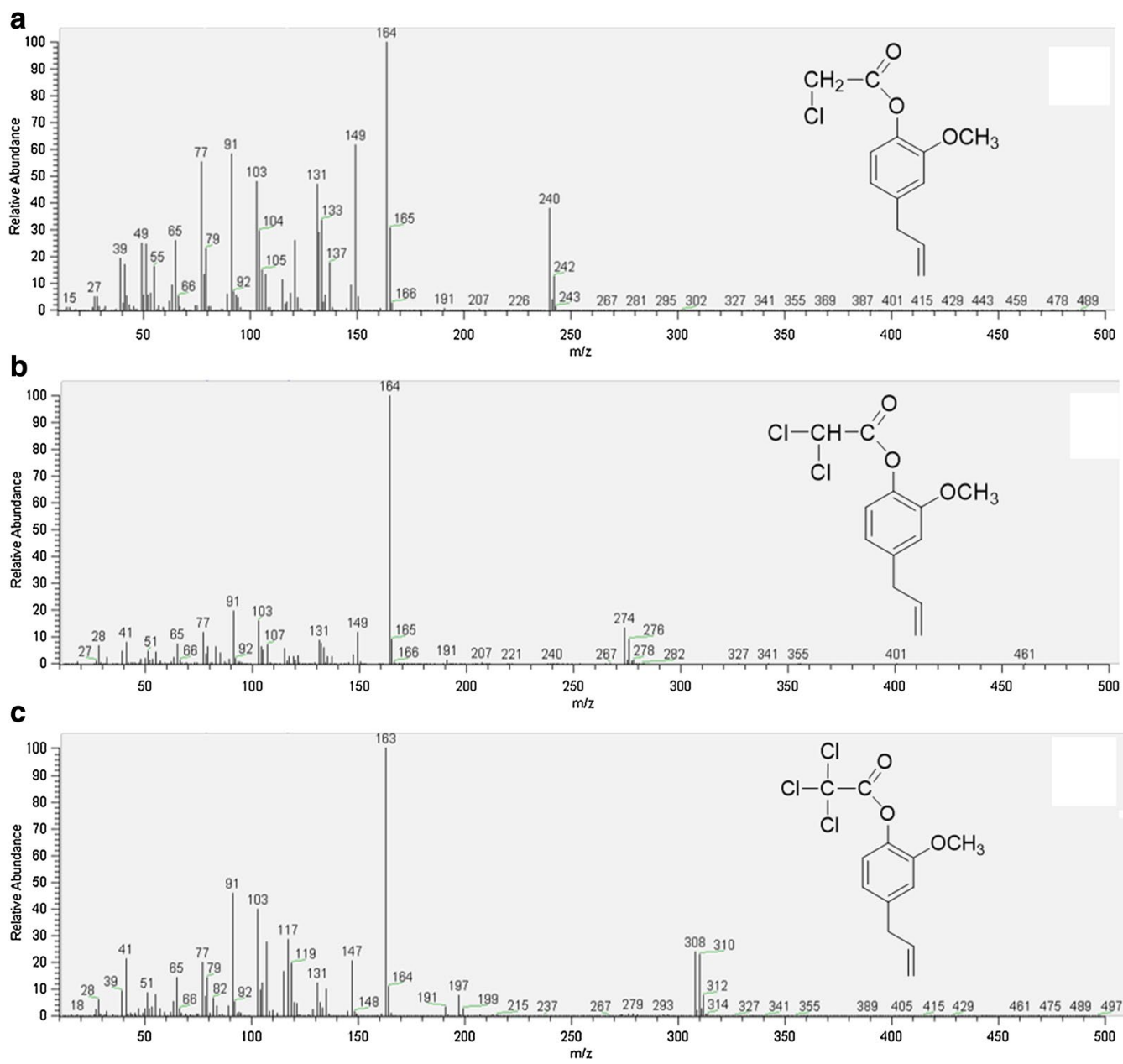

Fig. 3 Mass spectra: a eugenyl chloroacetate (EChA), b eugenyl dichloroacetate (EDChA), and c eugenyl trichloroacetate (ETChA)

The $\log \mathrm{P}$ values for dichloroacetic acid and trichloroacetic acid (DChAA 0.80 and $0.95 \pm 0.002$, TChAA 1.42 and $1.51 \pm 0.002--$ Table 1$)$ were similar to the $\log \mathrm{P}$ values described in the literature. However, by comparing the literature data describing the partition coefficient values determined by the experimental and theoretical methods, we found that depending on the method used, $\log \mathrm{P}$ values ranged from 2.13 to 2.66 (in the case of eugenol), from 0.92 to 1.06 (in the case of dichloroacetic acid), and from 1.17 to 1.53 (in the case of trichloroacetic acid). There is no data in the literature describing the partition coefficient values that have been determined for ester derivatives such as eugenyl chloroacetate (EChA), eugenyl dichloroacetate (EDChA), and eugenyl trichloroacetate (ETChA). Eugenol ester derivatives are considered nonionized substances. Due to the neutral nature of these compounds, their solubility is not dependent on the $\mathrm{pH}$ of the environment. Under the conditions of the experiment, there is no dissociation of esters to ionized forms, which would significantly disturb the solubility profiles of the derivatives obtained (Kuo et al. 2009; Ginting et al. 2019; Pernin et al. 2019; Sangster 1993, 1997, 2009; Hansch 1996; Howard and Meylan 1997).

The values of the antioxidant activity of the tested compounds (at a concentration of $1 \% \mathrm{w} / \mathrm{v}$ ) were $1.23 \pm 0.01 \mathrm{mmol} \mathrm{TE} / \mathrm{dm}^{3}$ (for eugenol), $0.32 \pm 0.01 \mathrm{mmol} \mathrm{TE} / \mathrm{dm}^{3}$ (for EChA), $1.08 \pm 0.02 \mathrm{mmol}$ $\mathrm{TE} / \mathrm{dm}^{3}$ (for EDChA), and $1.04 \pm 0.01 \mathrm{mmol} \mathrm{TE} / \mathrm{dm}^{3}$ (for ETChA), respectively-Table 2. Both eugenol and its ester derivatives with the highest values of antioxidant activity (i.e., EDChA and ETChA) were assessed for penetration through pig skin using the Franz diffusion chamber.

Table 2 presents the results for the antioxidant activity of solutions of the tested compounds, carried out by the DPPH method. 


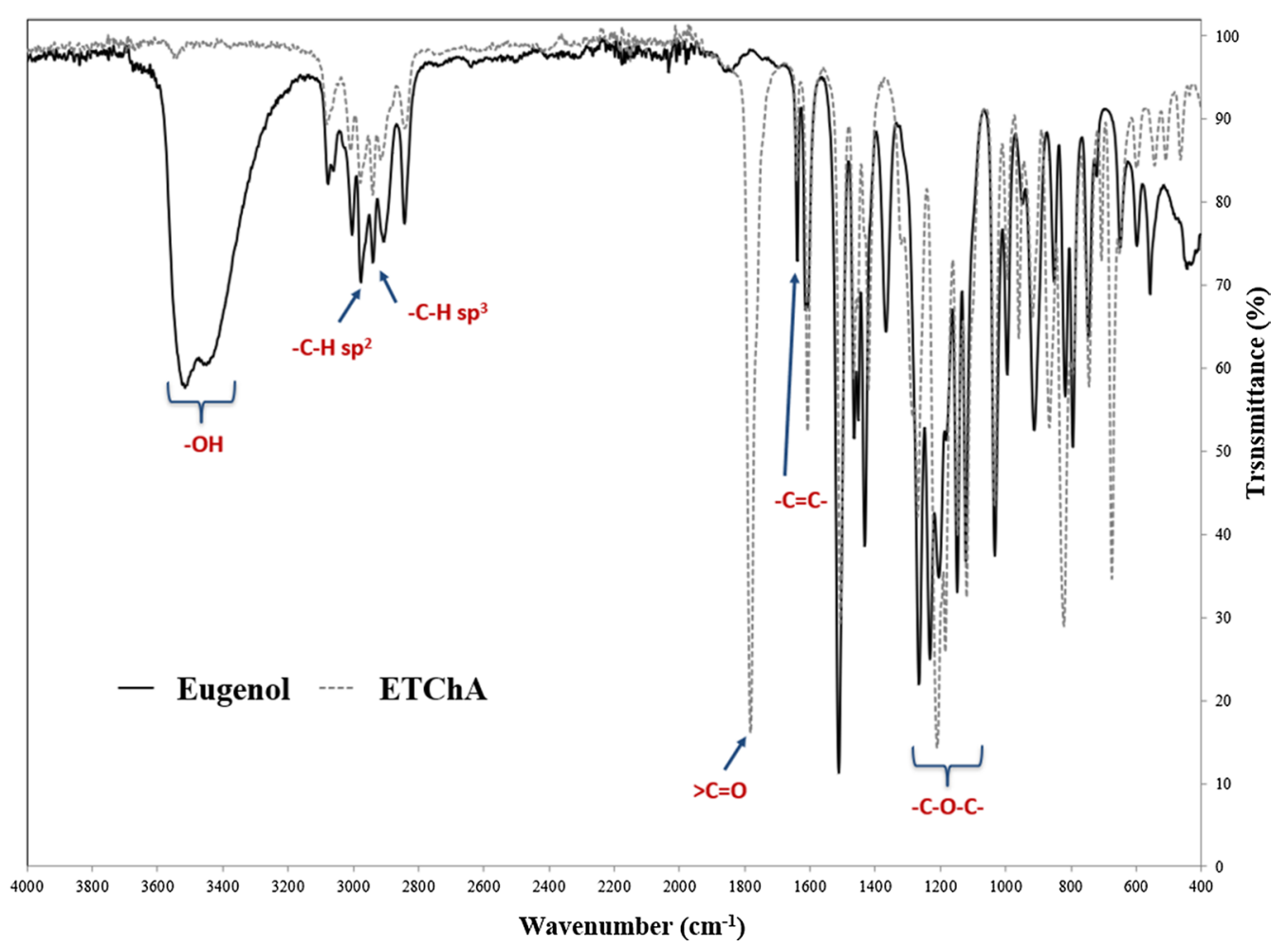

Fig. 4 Example of the IR spectrum of eugenol and ETChA

Table 1 Comparison of octanol/water partition coefficient values determined by the shake-flask method and calculated by the theoretical method

\begin{tabular}{lll}
\hline Compound & $\log \mathbf{P}^{\mathbf{1}}$ average value & $\log \mathbf{P}^{\mathbf{2}}$ \\
\hline Eugenol & $2.20 \pm 0.001 \mathrm{C}$ & 2.49 \\
EChA & $2.43 \pm 0.001 \mathrm{ab}$ & 3.11 \\
EDChA & $2.65 \pm 0.001 \mathrm{ab}$ & 3.73 \\
ETChA & $2.75 \pm 0.002 \mathrm{a}$ & 4.35 \\
DChAA & $0.95 \pm 0.002 \mathrm{e}$ & 0.80 \\
TChAA & $1.51 \pm 0.002 \mathrm{~d}$ & 1.42
\end{tabular}

1 determined by the shake-flask method; mean \pm S.D. $(n=3)$

$2 \log \mathrm{P}$ calculated in the MestReNova program, different letters-values are significantly different, mass substance in the acceptor fluid $(P<0.001)$

Table 3 presents the results for the antioxidant activity of the solutions of the tested compounds, carried out using the ABTS method.

Table 4 shows the total polyphenol content in solutions of the tested compounds, carried out using the FolinCiocalteu method.

The test results, presented in Tables 2, 3 and 4, show that the initial solutions of the tested compounds (eugenol, EDChA, ETChA) applied to the skin, solutions of acceptor liquids, and solutions obtained after skin extraction were characterized by high antioxidant activity.
Table 2 Antioxidant activity of $1 \%$ solutions of the test compounds applied to the skin, acceptor fluid obtained after $24 \mathrm{~h}$ of collection, and solutions obtained after skin extraction

\begin{tabular}{llll}
\hline Compound & \multicolumn{3}{l}{ Antioxidant activity (DPPH method) } \\
\cline { 2 - 4 } & $\begin{array}{l}\text { Solution } \\
\text { applied } \\
\text { to the skin } \\
\text { mmol TE/dm }\end{array}$ & $\begin{array}{l}\text { Acceptor fluid } \\
\text { after } \mathbf{2 4} \mathbf{h} \\
\text { of penetration }\end{array}$ & $\begin{array}{l}\text { Solution } \\
\text { after skin } \\
\text { extraction }\end{array}$ \\
\hline Eugenol* $^{*}$ & $1.23 \pm 0.01 \mathrm{a}$ & $0.08 \pm 0.01 \mathrm{a}$ & $0.22 \pm 0.02 \mathrm{~b}$ \\
EDChA $^{*}$ & $1.08 \pm 0.02 \mathrm{~b}$ & $0.07 \pm 0.00 \mathrm{a}$ & $0.25 \pm 0.01 \mathrm{a}$ \\
ETChA $^{*}$ & $1.04 \pm 0.01 \mathrm{c}$ & $0.06 \pm 0.00 \mathrm{a}$ & $0.21 \pm 0.01 \mathrm{~b}$ \\
DChAA & No activity & No activity & No activity \\
TChAA & No activity & No activity & No activity
\end{tabular}

* Mean \pm S.D. $(n=3)$, different letters - values are significantly different, mass substance in the acceptor fluid $(P<0.001)$

In the case of studies carried out for pure TChAA and DChAA, no antioxidant activity was shown.

The results of the studies on the antioxidant activity of acceptor fluid solutions (collected after $24 \mathrm{~h}$ of permeation) showed that the tested solution were characterized by antioxidant activity due to of eugenol and its esters. The degree of reduction of the DPPH free radical increased in the following order: $0.08 \pm 0.01 \mathrm{mmol}$ 
Table 3 Antioxidant activity of $1 \%$ solutions of the test compounds applied to the skin, acceptor fluid obtained after $24 \mathrm{~h}$ of collection, and solutions obtained after skin extraction

\begin{tabular}{llll}
\hline Compound & \multicolumn{3}{l}{ Antioxidant activity (ABTS method) } \\
\cline { 2 - 4 } & $\begin{array}{l}\text { Solution } \\
\text { applied } \\
\text { to the } \mathbf{s k i n}\end{array}$ & $\begin{array}{l}\text { Acceptor fluid } \\
\text { after } \mathbf{2 4} \mathbf{~} \\
\text { of penetration } \\
\mathbf{m m o l ~ T E} / \mathbf{d m}^{\mathbf{3}}\end{array}$ & $\begin{array}{l}\text { Solution } \\
\text { after skin } \\
\text { extraction }\end{array}$ \\
\hline Eugeno $^{*}$ & $4.74 \pm 0.01 \mathrm{a}$ & $0.25 \pm 0.03 \mathrm{a}$ & $0.91 \pm 0.02 \mathrm{C}$ \\
EDChA * $^{*}$ & $4.70 \pm 0.02 \mathrm{a}$ & $0.19 \pm 0.03 \mathrm{a}$ & $1.14 \pm 0.02 \mathrm{a}$ \\
ETChA $^{*}$ & $4.71 \pm 0.01 \mathrm{a}$ & $0.20 \pm 0.07 \mathrm{a}$ & $1.03 \pm 0.07 \mathrm{~b}$ \\
DChAA & No activity & No activity & No activity \\
TChAA & No activity & No activity & No activity \\
\hline
\end{tabular}

${ }^{*}$ Mean \pm S.D. $(n=3)$, different letters - values are significantly different, mass substance in the acceptor fluid $(P<0.001)$

Table 4 Total polyphenol content in solutions of test compounds applied to the skin, acceptor fluid solutions obtained after $24 \mathrm{~h}$ of collection, and solutions obtained after skin extraction

\begin{tabular}{llll}
\hline Compound & \multicolumn{3}{l}{ Antioxidant activity (Folin-Ciocalteu method): } \\
\cline { 2 - 4 } & $\begin{array}{l}\text { Solution } \\
\text { applied } \\
\text { to the skin } \\
\text { mmol gallic acid } / \mathbf{d m}^{\mathbf{3}}\end{array}$ & $\begin{array}{l}\text { Acceptor fluid } \\
\text { after } \mathbf{2 4} \mathbf{~} \\
\text { of penetration }\end{array}$ & $\begin{array}{l}\text { Solution } \\
\text { after skin } \\
\text { extraction }\end{array}$ \\
\hline Eugenol* $^{*}$ & $3.84 \pm 0.05 \mathrm{a}$ & $0.27 \pm 0.01 \mathrm{a}$ & $0.41 \pm 0.03 \mathrm{~b}$ \\
EDChA * $^{*}$ & $3.27 \pm 0.10 \mathrm{~b}$ & $0.22 \pm 0.01 \mathrm{~b}$ & $0.58 \pm 0.04 \mathrm{a}$ \\
ETChA $^{*}$ & $3.35 \pm 0.06 \mathrm{~b}$ & $0.25 \pm 0.01 \mathrm{ab}$ & $0.55 \pm 0.01 \mathrm{a}$ \\
DChAA $_{\text {TChAA }}$ & No activity & No activity & No activity \\
\hline
\end{tabular}

* Mean \pm S.D. $(n=3)$, different letters - values are significantly different, mass substance in the acceptor fluid $(P<0.001)$

$\mathrm{TE} / \mathrm{dm}^{3}$ (in the case of eugenol) $>0.07 \pm 0.00 \mathrm{mmol} \mathrm{TE} /$ $\mathrm{dm}^{3}$ (in the case of EDChA) $>0.06 \pm 0.00 \mathrm{mmol} \mathrm{TE} / \mathrm{dm}^{3}$ (for ETChA) (Table 2).

The antioxidant activity (determined by the ABTS method) of the compound solutions (eugenol, EDChA, ETChA) tested prior to application to the skin changed as follows: $4.74 \pm 0.01 \mathrm{mmol} \mathrm{TE} /$ $\mathrm{dm}^{3}$ (for eugenol) $>4.71 \pm 0.01 \mathrm{mmol} \mathrm{TE} / \mathrm{dm}^{3}$ (for ETChA) $>4.70 \pm 0.02 \mathrm{mmol} \mathrm{TE} / \mathrm{dm}^{3}$ (for EDChA) (Table 3). The results of studies on the antioxidant activity of acceptor fluid solutions (collected after $24 \mathrm{~h}$ of permeation) showed that the eugenol solutions tested had the highest antioxidant activity $\left(0.25 \pm 0.03 \mathrm{mmol} \mathrm{TE} / \mathrm{dm}^{3}\right)$. Lower antioxidant activity
Table 5 Results of studies on the penetration of active substances through pig skin and the amounts of extracted active ingredients accumulated in it

\begin{tabular}{lll}
\hline Compound & $\begin{array}{l}\text { Mass of substance } \\
\text { in the acceptor fluid after } \mathbf{2 4} \\
\mathbf{h} \text { of penetration } \\
(\boldsymbol{\mu g})\end{array}$ & $\begin{array}{l}\text { Concentration } \\
\text { of substance extracted } \\
\text { from the skin } \\
\left(\boldsymbol{\mu g} / \mathbf{c m}^{2} \text { skin) }\right.\end{array}$ \\
\hline Eugenol* $^{*}$ & $272.89 \pm 54.64 \mathrm{ab}$ & $566.93 \pm 33.34 \mathrm{a}$ \\
EDChA $^{*}$ & $302.77 \pm 1.90 \mathrm{~b}$ & $555.09 \pm 53.22 \mathrm{a}$ \\
ETChA $^{*}$ & $297.62 \pm 24.97 \mathrm{~b}$ & $539.14 \pm 40.53 \mathrm{a}$ \\
DChAA $^{*}$ & $247.63 \pm 16.45 \mathrm{ab}$ & $750.82 \pm 44.62 \mathrm{~b}$ \\
TChAA $^{*}$ & $210.54 \pm 16.45 \mathrm{a}$ & $799.41 \pm 39.99 \mathrm{~b}$
\end{tabular}

* Mean \pm S.D. $(n=3)$, different letters - values are significantly different, mass substance in the acceptor fluid $(P<0.05)$, concentration of substance extracted from the skin $(P<0.001)$

was observed for the ETChA and EDChA solutions $\left(0.19 \pm 0.03\right.$ and $0.20 \pm 0.07 \mathrm{mmol}$ of TE $\left./ \mathrm{dm}^{3}\right)$ (Table 3).

Test results obtained by the Folin-Ciocalteu method showed that the polyphenol contents of the initial solutions applied to the skin changed as follows: $3.84 \pm 0.05 \mathrm{mmol}$ of gallic acid $/ \mathrm{dm}^{3}$ (for eugenol) $>3.35 \pm 0.06 \mathrm{mmol}$ of gallic acid $/ \mathrm{dm}^{3}$ (for ETChA) $>3.27 \pm 0.10 \mathrm{mmol}$ of gallic acid $/ \mathrm{dm}^{3}$ (for EDChA) (Table 4). The results of tests for antioxidant activity of acceptor fluid solutions (collected after $24 \mathrm{~h}$ of permeation) showed that the tested eugenol solutions had the highest polyphenol content $\left(0.27 \pm 0.01 \mathrm{mmol}\right.$ gallic acid $\left./ \mathrm{dm}^{3}\right)$. Lower concentrations of $0.25 \pm 0.01$ and $0.22 \pm 0.01 \mathrm{mmol}$ of gallic acid $/ \mathrm{dm}^{3}$, respectively, were measured for solutions of ETChA and EDChA (Table 4).

The results of studies on the antioxidant activity of solutions obtained after skin extraction taken after the experiment showed that both eugenol and its ester derivatives were characterized by high antioxidant activity, as estimated by the three techniques mentioned: $\mathrm{DPPH}, \mathrm{ABTS}$, and Folin-Ciocalteu. The degree of DPPH free radical reduction for these compounds increased in the following order: EDChA $(0.25 \pm 0.01 \mathrm{mmol} \mathrm{TE} /$ $\left.\mathrm{dm}^{3}\right)>$ Eugenol $\left(0.22 \pm 0.02 \mathrm{mmol} \mathrm{TE} / \mathrm{dm}^{3}\right)>$ ETChA $\left(0.21 \pm 0.01 \mathrm{mmol} \mathrm{TE} / \mathrm{dm}^{3}\right)$ (Table 2).

In contrast, the antioxidant activity (ABTS method) of the solutions obtained after skin extraction changed as follows: $1.14 \pm 0.02 \mathrm{mmol} \mathrm{TE} /$ $\mathrm{dm}^{3}$ (for EDChA) $>1.03 \pm 0.07 \mathrm{mmol} \mathrm{TE} / \mathrm{dm}^{3}$ (for ETChA) $>0.91 \pm 0.02 \mathrm{mmol}$ of $\mathrm{TE} / \mathrm{dm}^{3}$ (for eugenol) (Table 3). The research results obtained by the FolinCiocalteu method showed that the values of antioxidant activity of solutions obtained after skin extraction (ETChA and EDChA) were higher $(0.55 \pm 0.01$ and $0.58 \pm 0.04 \mathrm{mmol}$ of gallic acid $/ \mathrm{dm}^{3}$ ) than the values of 
antioxidant activity of eugenol $(0.41 \pm 0.03 \mathrm{mmol}$ gallic acid/ $\mathrm{dm}^{3}$ ) (Table 4).

Table 5 presents the results of studies on the penetration of active substances through pig skin and the amounts of extracted active ingredients accumulated in the skin.

Figure 5 shows the results of studies on the permeation of active substances through pig skin during the 24-h experiment.

In our own research conducted in vitro, the penetration of eugenol and its new ester derivatives (EDChA, ETChA) through pig skin was assessed. For comparative purposes, tests were also carried out for pure acids (DChAA, TChAA). The experiment was carried out using a Franz diffusion chamber, in which the donor phase consisted of ethanol solutions of the compounds tested. The acceptor phase was PBS solution, because it corresponds to systemic conditions, is isotonic in nature, and allows conditions corresponding to the conditions prevailing in the deeper layers of the skin to be maintained (Alonso et al. 2014). Permeation of test substances through pig skin into the acceptor fluid increased in the following order: EDChA $>$ ETChA $>$ Eugenol $>$ DChAA $>$ TChAA. After conducting the experiment for $24 \mathrm{~h}$, the highest average cumulative mass was observed in the case of EDChA $(302.77 \pm 1.90 \mu \mathrm{g})$. The mass was slightly lower in the case of ETChA $(297.62 \pm 24.97 \mu \mathrm{g})$ and for eugenol $(272.89 \pm 54.64 \mu \mathrm{g})$. In addition, the study showed that amount of ETChA penetration differed significantly from that of TChAA $(210.54 \pm 16.45 \mu \mathrm{g})$. The highest increase in the penetration rate of EDChA to the acceptor fluid $\left(\mu \mathrm{g} / \mathrm{cm}^{2} / \mathrm{h}\right)$ was observed between 2 and $3 \mathrm{~h}$, while for ETChA and eugenol, it was between 3 and $4 \mathrm{~h}$ (Fig. 5).

After the experiment was carried out, the skin was extracted in order to extract the tested active ingredients accumulated in it. The obtained test results showed that the concentration of tested substances in the analyzed extracts $\left(\mu \mathrm{g} / \mathrm{cm}^{2}\right.$ skin) decreased in the following order: TChAA $(799.41 \pm 39.99 \mu \mathrm{g} /$ $\mathrm{cm}^{2} \quad$ skin $)>$ DChAA $\quad(750.82 \pm 44.62 \quad \mu \mathrm{g} /$ $\mathrm{cm}^{2} \quad$ skin $)>$ eugenol $\quad\left(566.93 \pm 33.34 \quad \mu \mathrm{g} / \mathrm{cm}^{2}\right.$ skin $)>$ EDChA $\quad\left(555.09 \pm 53.22 \mu \mathrm{g} / \mathrm{cm}^{2} \quad\right.$ skin $)>$ ETChA $\left(539.14 \pm 40.53 \mu \mathrm{g} / \mathrm{cm}^{2}\right.$ skin). Pure TChAA and DChAA acids were accumulated in the skin, as evidenced by the high concentrations of compounds found in the analyzed extracts: TChAA $\left(799.41 \pm 39.99 \mu \mathrm{g} / \mathrm{cm}^{2}\right.$ skin $)$ and DChAA $\left(750.82 \pm 44.62 \mu \mathrm{g} / \mathrm{cm}^{2}\right.$ skin) (Table 5). The factor significantly affecting the transport of active substances is the lipophilicity of the test compound (Yang et al. 2008; Srinivas et al. 2019; Ichihashi et al. 2003; Casagrande et al. 2007). The optimal log P coefficient (which is an indicator of the lipophilicity of the active substance) is in the range of 2 to 3 (Janus et al. 2020; Haq et al. 2018; Simon et al. 2016). This was also confirmed in our own research, which showed that both eugenol and its ester derivatives were characterized by good permeability through the skin (log P: Eugenol $2.20 \pm 0.001$, EDChA $2.65 \pm 0.001$, ETChA $2.75 \pm 0.002$, Table 1). Lipophilic compounds penetrate much more easily through the skin, because the skin consist mainly of lipid substances which, at the same time, limits the penetration of hydrophilic substances (log P: DChAA $0.95 \pm 0.002$, TChAA $1.51 \pm 0.002$, Table 1) commonly used in dermatology or cosmetology (Jaworska et al. 2011). The lower lipophilicity of the compound $(\log \mathrm{P}<2)$ is associated with its worse penetration the skin (Simon et al. 2016). This relationship was also confirmed in our own research; the average masses accumulated in the acceptor fluid after $24 \mathrm{~h}$ were $247.63 \pm 16.45$ (in the case of DChAA) and $210.54 \pm 16.45$ (in the case of TChAA), as shown in Table 5, while the average cumulative masses for these compounds at $0.5 ; 1 ; 2 ; 3 ; 4 ; 5 ; 8$, and $24 \mathrm{~h}$ are shown in Fig. 5.
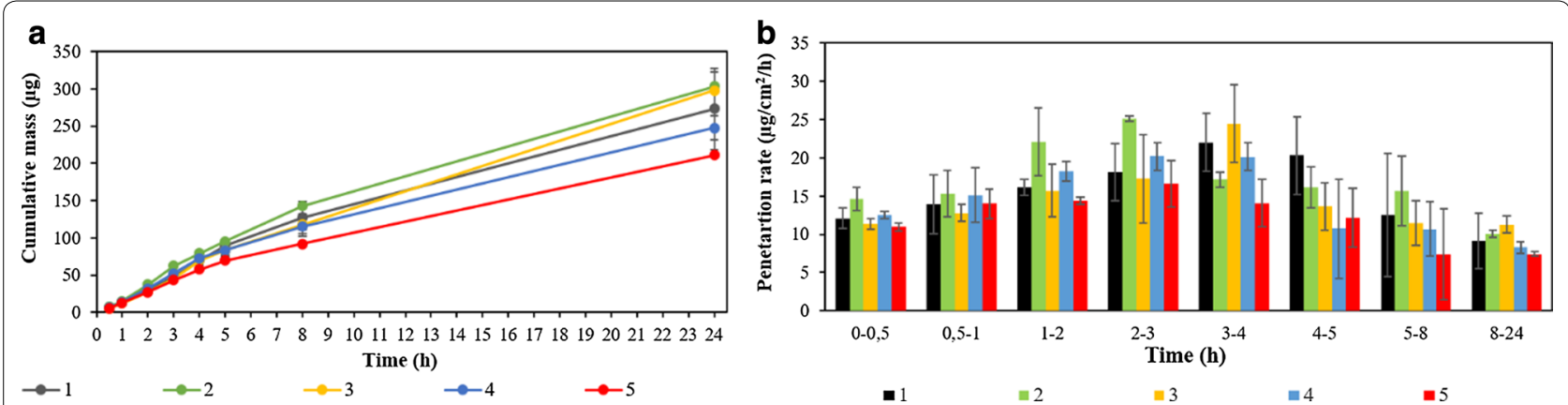

Fig. 5 a Mass of test substance in the acceptor fluid during the 24-h experiment: (1) Eugenol, (2) EDChA, (3) ETChA, (4) DChAA, (5) TChAA. b The penetration rate of test substances through the skin during the 24-h experiment: (1) Eugenol, (2) EDChA, (3) ETChA, (4) DChAA, (5) TChAA 


\section{Discussion}

The antioxidant activity of eugenol and EDChA depends on the concentration of antioxidant in the test sample. As it has been shown in our previous studiy (Makuch et al. 2019), the antioxidant activity of the sample increased as from $76 \%$ (for $0.25 \mu \mathrm{g} / \mathrm{ml}$ ) to $88 \%$ RSA (for $5 \mu \mathrm{g} / \mathrm{ml}$ ). The antioxidant activity of eugenol increases with an increase of this compound concentration in the tested sample due to a reduced electron density on the oxygen atom of the phenolic group (i.e. the $-\mathrm{OH}$ group associated with carbon of the aromatic ring). The hydrogen bonding energy is much lower, which makes it easier to give it to the DPPH radical (through the reaction of the radical and antioxidant molecule with the formation of the adduct). Other studies have shown that the values of the parameter determining the concentration reducing $50 \%$ of free radicals $\left(\mathrm{IC}_{50}\right)$ for eugenol are inversely proportional to its antioxidant activity. The lower the $\mathrm{IC}_{50}$, the higher the antioxidant activity (Makuch et al. 2019).

The results of EDChA antioxidant activity presented in Table 2, showed that the antioxidant activity may be strongly influenced by the kinetic behavior of this compound. As our previous research has shown (Makuch et al. 2019), by increasing the concentration of EDChA in the tested sample, a decrease in antioxidant activity was observed: from 93\% (at $0.25 \mu \mathrm{g} / \mathrm{ml}$ ester concentration) to $89 \% \mathrm{RSA}$ (at $5 \mu \mathrm{g} / \mathrm{ml}$ ester concentration). The reason for under-activation is that the reaction time (10 $\mathrm{min}$ ) between DPPH and EDChA is too short. As a result, this time prevents the end of the reaction between radical and antioxidant. This phenomenon is most often observed in the case of antioxidants (essential oils, compounds isolated from plant materials or plant extracts) characterized by a slow reaction with DPPH radical (CenobioGalindo et al. 2019; Fadda et al. 2014; Magalhaes et al. 2012; Ahmad et al. 2012).

Eugenol has a hydroxyl group $(-\mathrm{OH})$ associated with an aromatic ring with acidic properties, which could lead to antioxidant activity. Its free radicals scavenging activity could lead to form phenolic radicals. These radicals are stable due to resonance caused charge transfer and are not able to detach hydrogen from lipid or protein molecules (and to decrease the oxidation).

Replacement of hydrogen atoms in the aliphatic chain EChA, EDChA and ETChA by heteroatoms (in this case, chlorine atoms) enhances the antioxidative properties. Eugenol esters containing chlorine atoms in the structure easily trap free radicals, giving up the $\mathrm{H}$ atom in the aliphatic chain. The reason is a change in the shape of the molecule, i.e. a change in length, direction, range and polarization of the bonds and a change in the symmetry of the particles. Introduction of chlorine atoms into the structure, causes polarization of bonds between carbon-chlorine atoms. The polarization of bonds between the carbon-chlorine atoms reduces the density of the electron cloud in the whole molecule and causes polarization of all close bonds present in the structure. As a result of this bond between the carbon-hydrogen atoms in EChA, EDChA and ETChA molecules, they change their length and polarity. In addition, the presence of chlorine atoms in the structure of these compounds changes the electro-neutrality of carbon atoms. Additionally, the presence of the methoxyl group ($\left.\mathrm{OCH}_{3}\right)$ in the eugenol molecule and the EChA, EDChA and ETChA molecules increases the antioxidant properties of these compounds (Rice-Evans et al. 1996).

We demonstrated that new eugenol derivatives (EDChA and ETChA) containing ester groups, penetrate more readily through biological membranes. They are characterised by higher partition coefficient compared to the parent output eugenol and acids (DChAA and TChAA), which can have a positive impact on enhance active substance transport through biological membranes. Eugenol is a terpene compound classified as an absorption promoter that is characterized by high antibacterial (Makuch et al. 2016; Pavithra 2014) as well as antioxidant activity (Hamed et al. 2012; Promod et al. 2010. Terpenes, which are a group of substances that are commonly considered safe from the point of view of dermal toxicity, are often used in preparations applied to the outer layer of the skin (Makuch et al. 2017; Ahad et al. 2016; Pavithra 2014).

The transport of the active substance the skin also depends on the molecular weight of the active substance itself. Overcoming the lipophilic barrier, which is the skin, is possible for non-polar-new esters of eugenol, which have molecular weights of $<600 \mathrm{Da}$ (Malinowska et al. 2013; Tan et al. 2015; Thi and Hwang 2014). Besides better absorption of active substance by penetrating faster, the presented esters can provide endogenous action against free radicals, which is their superiority to the used in cosmetology acids ( $\alpha$ - and $\beta$-hydroxy acids, TChAA), for which the skin is a barrier limiting their penetration. Data in the literature indicate that after a single application of trichloroacetic acid, complete epidermal necrolysis occurs, resulting in a decrease in capillary permeability. Therefore, after application of TChAA, no irritation or inflammation of the skin was observed (Sarkar 2012; Pathan and Setty 2009). In contrast, these symptoms occur after the application of commonly used $\alpha$ - and $\beta$-hydroxy acids (AHA and BHA). EDChA and ETChA are alternatives to AHA, BHA, and TChAA, which are active substances commonly used in problem skin care that have a tendency to cause imperfections (Karolak et al. 2017; Pathan and Setty 2009). 
In addition, the good permeability of EDChA and ETChA through the skin and their proper accumulation in the skin (Table 5; Fig. 5) as well as their antioxidant capacity (Tables 2, 3 and 4) can limit also the exogenous effects of free radicals. Free radicals are highly reactive, toxic molecules due to the presence of one or more impaired electrons. Within tissue they damage DNA, proteins, lipids and carbohydrates (Dhale et al. 2007). The reactivity of new esters of eugenol by donating their electrons to the free radicals suggested use EDChA and ETChA as antioxidant.

In recent years, antioxidants have increasingly been used as active ingredients in cosmetic and pharmaceutical preparations, because they act as ROS blockers. Among the huge group of antioxidants, clove oil and eugenol (the main component of clove oil) can be distinguished as having confirmed antioxidant and antimicrobial effects. Although eugenol, as a biologically active substance, is already used in many cosmetic and pharmaceutical preparations the antioxidant effect of eugenol after crossing the skin barrier has not previously been studied. In addition, the use of new eugenol derivatives (EDChA, ETChA) as biologically active substances increases their penetration (as confirmed in our own research) of the skin and could decrease the toxic effect of exogenous and endogenous ROS. The obtained derivatives were characterized by high antioxidant activity, which was estimated after $24 \mathrm{~h}$ of conducting the experiment, which indicates long-term protection against ROS in the deeper layers of the skin. In the presented studies, the relationship between the lipophilicity of each tested active substance and its antioxidant capacity was estimated. The research presented in this publication thus provides new knowledge to this area of research (Li et al. 2011; Makuch et al. 2016; Makuch et al. 2015; Makuch and Kądziołka 2018; Wróblewska et al. 2017; Makuch et al. 2017; Makuch and Wróblewska 2014; Pavithra 2014; Hamed et al. 2012).

\section{Acknowledgements \\ Not applicable.}

\section{Authors' contributions}

Conceptualization, EM and AN; Writing - review \& editing, EM, AN and AG; Methodology, EM, AN, WD and ŁK; Reviewing RP and AK; Formal analysis, AN, $E M$ and $Ł K$; Investigation $A N$, ŁK and EM; Writing-original draft, AN and EM; Supervision, AK and RP. All authors read and approved the final manuscript.

\section{Funding}

Not applicable.

\section{Availability of data and materials}

Not applicable.

Ethics approval and consent to participate Not applicable.
Consent for publication

Not applicable.

\section{Competing interests}

The authors declare that they have no competing interests.

Received: 25 September 2020 Accepted: 5 October 2020

Published online: 19 October 2020

\section{References}

Agati G, Azzarello E, Pollastri S, Tattini M (2012) Flavonoids as antioxidants in plants: location and functional significance. Plant Sci 196:67-76

Ahad A, Aqil M, Ali A (2016) The application of anethole, menthone, and eugenol in transdermal penetration of valsartan: enhancement and mechanistic investigation. Pharm Biol 54(6):1042-1051

Ahmad N, Fazal H, Ahmad I, Abbasi BH (2012) Free radical scavenging (DPPH) potential in nine Mentha species. Toxicol Ind Health 28(1):83-89

Alonso C, Rubioa L, Touriñob S, Martía M, Barbaa C, Fernández-Camposc F, Codercha L, Parraa JL (2014) Antioxidative effects and percutaneous absorption of five polyphenols. Free Radic Biol Med 75:149-155

Arung ET, Matsubara E, Wijaya K, Sukaton E, Shimizu K, Kondo R (2011) Inhibitory components from the buds of clove (Syzygium aromaticum) on melanin formation in B16 melanoma cells. Fitoter 82(2):198-202

Arung ET, Shimizu K, Kondo R (2007) Structure-activity relationship of prenylsubstituted polyphenols from Artocarpus heterophyllus as inhibitors of melanin biosynthesis in cultured melanoma cells. Chem Biodivers 4(9):2166-2171

Badran MM, Kuntsche J, Fahr A (2009) Skin penetration enhancement by a microneedle device (Dermaroller ${ }^{\circledR}$ ) in vitro: dependency on needle size and applied formulation. Eur J Pharm Sci 36:511-523

Benzie IFF, Strain JJ (1996) The ferric reducing ability of plasma (FRAP) as a measure of antioxidant power: The FRAP assay. Anal Biochem 239(1):70-76

Brand-Williams W, Cuvelier ME, Berset CLWT (1995) Use of free radical method to evaluate antioxidant activity. LWT - Food Sci Technol 28:25-30

Casagrande R, Georgetti SR, Verri WA, Borin FM, Lopez RFV, Fonseca MJV (2007) In vitro evaluation of quercetin cutaneous absorption from topical formulations and its functional stability by antioxidant activity. Int J Pharm 2(10):183-190

Cenobio-Galindo AJ, Pimentel-Gonzalez DJ, Razo-Rodriguez OE, Medina-Perez G, Carrillo-Inungaray ML, Reyes-Mungula A, Campos-Montiel RG (2019) Antioxidant and antibacterial activities of a starch film with bioextracts microencapsulated from cactus fruits (Opuntia oligacantha). Food Sci Biotechnol 28(5):1553-1561

Chaibakhsh N, Basri M, Mohamed ASH, Rahman AMB, Rezayee M (2012) Optimization of enzymatic synthesis of eugenol ester using statistical approaches. Biocatal Agric Biotechnol 1(3):226-231

Cichorek M, Wachulska M, Stasiewicz A, Tymińska A (2013) Skin melanocytes: Biology and development. Post Dermatol Alergol 30(1):30-41

Čuříková BA, Procházková K, Filková B, Diblíková P, Svoboda J, Kováčik A, Vávrová K, Zbytovská J (2017) Simplified stratum corneum model membranes for studying the effects of permeation enhancers. Int J Pharm 534(1-2):287-296

Davies DJ, Ward RJ, Heylings JR (2004) Multi-species assessment of electrical resistance as a skin integrity marker for in vitro percutaneous absorption studies. Toxicol In Vitro 18(3):351-358

Hansch C (1996) Exploring QSAR: hydrophobic, electronic, and steric constants. J Med Chem 39(5):1013-1192

Dhale MS, Divakar S, Kumar U, Vijayalakshmi G (2007) Isolation and characterization of dihydromonacolin-MV from Monascus purpureus for antioxidant properties. Appl Microbiol Biotechnol 73:1197-1202

Fadda A, Serra M, Molinu MG, Azara E, Barberis A, Sanna D (2014) Reaction time and DPPH concentration influence antioxidant activity and kinetic parameters of bioactive molecules and plant extracts in the reaction with the DPPH radical. J Food Compos Anal 35:112-119

Floegel A, Kim DO, Chung SJ, Koo SI, Chun OK (2011) Comparison of ABTS/ DPPH assays to measure antioxidant capacity in popular antioxidant-rich. J Food Compos Anal 24:1043-1048 
Ginting M, Surbakti D, Triana N (2019) Synthesis of 2-(4-Allyl-2-Methoxy Phenoxy)-N,N-Bis(2-Hydroxyethyl) Acetamide from the transformation of eugenol isolated from clove oil. J Chem Nat Resour 01(01):31-39

Gulcin I (2011) Antioxidant activity of eugenol: a structure-activity relationship study. J Med Food 14(9):975-985

Hamed SF, Sadek Z, Edris A (2012) Antioxidant and antimicrobial activities of clove bud essential oil and eugenol nanoparticles in alcohol-free microemulsion. J Oleo Sci 61(11):641-648

Haq A, Michniak-Kohn B (2018) Effects of solvents and penetration enhancers on transdermal delivery of thymoquinone: permeability and skin deposition study. Drug Deliv 25(1):1943-1949

Horchani H, Salem BN, Zarai Z, Sayari A, Gargouri Y, Chaâbouni M (2010) Enzymatic synthesis of eugenol benzoate by immobilized Staphylococcus aureus lipase: Optimization using response surface methodology and determination of antioxidant activity. Bioresour Technol 101(8):2809-2817

Howard PH, Meylan WM (1997) Handbook of physical properties of organic chemicals. Lewis Publishers (CRC Press cop, Michigan, p 1585

Ichihashi M, Ueda M, Budiyanto A, Bito T, Oka M, Fukunaga M, Tsuru K, Horikawa T (2003) UV-induced skin damage. Toxicology. 189(1-2):21-39

Igielska-Kalwat J, Gościańska J, Nowak I (2015) Carotenoids as natural antioxidants. Postępy Hig Med Dośw 69:418-428

IIntarakumhaeng R, Li SK (2014) Effects of solvent on percutaneous absorption of nonvolatile lipophilic solute. Int J Pharm 476(1-2):266-276

Janiuk M, Najda A, Gantner M, Błażewicz-Woźniak M (2013) Chemical variability and antioxidant activity of the leaves of chosen highbush blueberry (Vaccinium corymbosum I) Cultivars. Modern Phytomorph 3:111-114

Janus E, Ossowicz P, Klebeko J, Nowak A, Duchnik W, Kucharski Ł, Klimowicz A (2020) Enhancement of ibuprofen solubility and skin permeation by conjugation with L-valine alkyl esters. RSC Adv 10:7570-7584

Jaworska M, Sikora E, Ogonowski J (2011) Factors influencing the percutaneous penetration of active ingerdients. Wiad Chem 65:3-4

Karolak M, Tyburski A, Krysiński J (2017) Permeation enhancers-substances affecting the penetration of drugs through the skin. Farm Pol 73(1):55-60

Kopečná M, Macháček M, Prchalová E, Štěpánek P, Drašar P, Kotora M, Vávrová K (2017) Galactosyl pentadecene reversibly enhances transdermal and topical drug delivery. Pharm Res 34(10):2097-2108

Kuntsche J, Bunjes H, Fahr A, Pappinen S, Rönkkö S, Suhonen M, Urtti A (2008) Interaction of lipid nanoparticles with human epidermis and an organotypic cell culture model. Inter J Pharm 354(1-2):180-195

Kuo SC, Chuang SK, Lin HY, Wang LH (2009) Study of the aerosol fragrances of eugenol derivatives in Cananga odorata using diffuse reflectance infrared Fourier transform spectroscopy and gas chromatography. Anal Chim Acta 653(1):91-96

Li L, Seeram NP (2010) Maple syrup phytochemicals include lignans, coumarins, a stilbene, and other previously unreported antioxidant phenolic compounds. J Agric Food Chem 58(22):11673-11679

Li X, Wang X, Chen DSC (2011) Antioxidant activity and mechanism of protocatechuic acid in vitro. Funct Foods Heal Dis 1(7):232-244

Magalhaes LM, Barreiros L, Maia MA, Reis S, Segundo MA (2012) Rapid assessment of endpoint antioxidant capacity of red wines through microchemical methods using a kinetic matching approach. Talanta 97(0):473-483

Malinowska M, Sikora E, Ogonowski J (2013) Percutaneous penetration of active cosmetics ingredients. Wiad Chem 67:3-4

Makuch E, Wróblewska A (2014) Przebieg procesu izomeryzacji eugenolu na heterogenicznych katalizatorach tytanowo-silikatowych TS-1 i TiMCM-41 o stosunku molowym Si/Ti w żelu krystalizacyjnym równym 15. In: Innowacje w polskiej nauce w obszarze inżynierii i technologii Wydawnictwo Nauka i Biznes. Brzeziny, Poland, pp 85-92

Makuch E, Kądziołka D (2018) Frakcje roślinne zawierające związki aktywne biologicznie a ich działanie przeciwgrzybowe. Postępy Technologii Inżynierii Chemicznej Wydawnictwo Zachodnioporskiego Uniwersytetu w Szczecinie, Poland, pp 151-160

Makuch E, Wróblewska A, Markowska-Szczupak A, Kucharski Ł, Klimowicz A (2015) Badania właściwości antymikrobiologicznych kremu z dodatkiem olejku goździkowego metodą krążkowo-dyfuzyjną. Innowacje w polskiej nauce - przegląd aktualnej tematyki badawczej branży chemicznej Wydawnictwo Zachodnioporskiego Uniwersytetu w Szczecinie. Poland 7:77-85

Makuch E, Wróblewska A, Kucharski Ł, Klimowicz A (2016) Ocena aktywności antyoksydacyjnej próbek kremu zawierającego olejek goździkowy metodą redukcji rodnika DPPH. Innowacje w polskiej nauce - przegląd aktualnej tematyki badawczej branży chemicznej Wydawnictwo Zachodnioporskiego Uniwersytetu w Szczecinie. Poland 6:67-75

Makuch E, Wróblewska A, Retajczyk M (2017) Wpływ czasu prowadzenia ekstrakcji nierozwiniętych pąków kwiatowych drzewa goździkowca wonnego na zawartość substancji biologicznie aktywnych w ekstraktach etanolowych. Postępy Technologii Inżynierii Chemicznej Wydawnictwo Zachodnioporskiego Uniwersytetu w Szczecinie, Poland: 110-118

Makuch E, Gołębiewska M, Günther A, Pełech R (2019) Synthesis, characteristits, and evaluation of properties of dichloroacetate of eugenyl. Postępy Technologii Inżynierii Chemicznej - Zastosowania metod inżynierii chemicznej Wydawnictwo Zachodnioporskiego Uniwersytetu w Szczecinie. Poland 12:127-138

Michalak A, Krzeszowiak J, Markiewicz-Górka I (2014) The correlations between aging of the human body, oxidative stress and reduced efficiency of repair systems. Postep Hig Med Dosw 68:1483-1491

Molyneux P (2004) The use of the stable free radical diphenylpicryl-hydrazyl (DPPH) for estimating antioxidant activity. Songklanakarin J Sci Technol 26(2):211-219

Nowak A, Klimowicz A, Duchniak W, Kucharski Ł, Florkowska K, Muzykiewicz A, Wira D, Zielonka-Brzezicka J, Siedłowska A, Nadarzewska K (2019) Application of green-extraction technique to evaluate of antioxidative capacity of wild population of fireweed (Epilobium angustifolium). Herba Pol 65(4):18-30

Nowak A, Zielonka-Brzezicka J, Pechaiko D, Tkacz M, Klimowicz A (2017) The evaluation of the antioxidant properties of Ginkgo biloba L. leaves after the end of the growing season. Pom J Life Sci 63(1):9-15

Pathan IB, Setty CM (2009) Chemical penetration enhancers for transdermal drug delivery systems. Trop J Pharm Res 8(2):173-179

Pavithra B (2014) Eugenol-A Review. J Pharm Sci Res 6(3):153-154

Pernin A, Bosc V, Maillard MN, Dubois-Brissonnet F (2019) Ferulic acid and eugenol have different abilities to maintain their inhibitory activity against Listeria monocytogenes in emulsified systems. Front Microbiol 10:1-10

Piwowarczyk D, Nowak A, Klimowicz A (2017) Suitability of lipophilic and hydrophilic artifi cial membranes for the evaluation of in vitro methyl p-hydroxybenzoate penetration. Pom J Life Sci 63(4):110-115

Promod K, Ansari SH, Ali J (2010) Eugenol: a natural compoumnd with versatile pharmcological actions. Nat Prod Commun 5(12):1999-2006

Rahim NHCA (2017) Synthesis and antibacterial study of eugenol derivatives. Asian J Chem 29(1):22-26

Rice-Evans C, Miller NJ, Paganga G (1996) Structure - antioxidant activity relationship of flavonoids and phenolic acids. Free Radic Biol Med 20(7):933-956

Sá AGA, Meneses AC, Araújo PHH, Oliveira D (2017) A review on enzymatic synthesis of aromatic esters used as flavor ingredients for food, cosmetics and pharmaceuticals industries. Trends Food Sci Technol 69:95-105

Sangster J (1993) LOGKOW - a databank of evaluated octanol-water partition coefficients. Sangster Research Laboratories Montreal: 1-15

Sangster J (1997) LOGKOW - a databank of evaluated octanol-water partition coefficients. Databanks Bulletin 1(1):1-3

Sangster J (2009) Octanol-water partition coefficients of simple organic compounds. J Phys Chem Ref Data 18(3):1-11

Sarkar R (2012) Chemical peels for Melasma in dark-skinned patients. J Cutan Aesth Surg 5(4):247-253

Simon A, Amaro MI, Healy AM, Cabral LM, de Sousa VP (2016) Comparative evaluation of rivastigmine permeation from a transdermal system in the Franz cell using synthetic membranes and pig ear skin with in vivo-in vitro correlation. Int J Pharm 512(1):234-241

Srinivas US, Tan BWQ, Vellayappan BA, Jeyasekharan AS (2019) ROS and the DNA damage response in cancer. Redox Biol 25:1-9

Suvarnakuta P, Chaweerungrat C, Devahastin S (2011) Effects of drying methods on assay and antioxidant activity of xanthones in mangosteen rind. Food Chem 125(1):240-247

Tan YS, Baskaran A, Nallathamby N, Chua KH, Kuppusamy UR, Sabaratnam V (2015) Influence of customized cooking methods on the phenolic contents and antioxidant activities of selected species of oyster mushrooms (Pleurotus spp). J Food Sci Technol 52:3058-3064

Thi ND, Hwang ES (2014) Bioactive compound contents and antioxidant activity in aronia (Aronia melanocarpa) leaves collected at different growth stages. Prev Nutr Food Sci 19(3):204-212 
Vanin AB, Orlando T, Piazza SP (2014) Antimicrobial and antioxidant activities of clove essential oil and eugenyl acetate produced by enzymatic esterification. Appl Biochem Biotechnol 174(4):1286-1298

Waszczuk P, Makuch E (2020) Comparative analysis of lipophility of ester derivatives of eugenol. Postępy Technologii Inżynierii Chemicznej Wydawnictwo Zachodnioporskiego Uniwersytetu w Szczecinie, Poland Wróblewska A, Makuch E, Kucharski Ł, Klimowicz A, Markowska-Szczupak A (2017) Antimicrobial studies on creams obtained with clove oil and with waste aqueous phase remaining after the clove oil distillation. Antimicrobial Res 6:31-43

Yang H, Wang X, Liu X, Wu J, Liu C, Gong W, Zhao Z, Homg J, Lin D, Wang Y, Lai $R$ (2008) Antioxidant peptidomics reveals novel skin antioxidant system. Mol Cell Proteomisc 8(3):571-583
Zhang A, Jung ECh, Zhu H, Zou Y, Hui X, Maibach H (2016) Vehicle effects on human stratum corneum absorption and skin penetration. Toxicol Ind Health 33(5):416-425

Zhao J (2015) Flavonoid transport mechanisms: how to go, and with whom. Trends Plant Sci 20(9):576-585

Zheng YZ (2017) Antioxidant activity of quercetin and its glucosides from propolis: a theoretical study. Sci Rep 7(7543):1-11

\section{Submit your manuscript to a SpringerOpen ${ }^{\circ}$ journal and benefit from:}

- Convenient online submission

- Rigorous peer review

- Open access: articles freely available online

- High visibility within the field

- Retaining the copyright to your article

Submit your next manuscript at $\boldsymbol{s p r i n g e r o p e n . c o m ~}$ 